\title{
Coast Defence from an Imperial Standpoint
}

\section{Colonel E. H. Cotter h.p., R.E.}

To cite this article: Colonel E. H. Cotter h.p., R.E. (1904) Coast Defence from an Imperial Standpoint, Royal United Services Institution. Journal, 48:315, 510-532, DOI: $\underline{10.1080 / 03071840409418319}$

To link to this article: http://dx.doi.org/10.1080/03071840409418319

\section{曲 Published online: 11 Sep 2009.}

Submit your article to this journal

\section{Џ Article views: 5}

Q View related articles $\sqsubset$ 


\section{COAST DEFENCE \\ FROM AN TMIPERIAL STANDPOIN'T.}

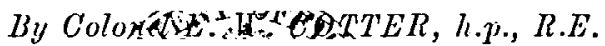

Wedne 17thebruary, 1904.

Major-General Sir Hoold marcumont, K.C.B., in the Chair.

IN a lecture limited in duration to one hour it would be impossiblo to treat the subject of Coast Defence in detail; I therefore confine myself first to a general outline of the principles on which, in $\mathrm{my}$ opinion, coast defence should be based, and follow with an illustration of the application of those principles.

A statesman has recently told us that he could never get an answer to the question: "What is the object of the British Army?" At last we seem to be agreed that to answer the question correctly it is necessary to study our whole Imperial position. Only when we have done that can we arrive at a sound decision as to the size and constitution, not merely of our Army, but of all the Services connected with national defence.

I asked myself, "What is the object of coast defence, what should be its nature, and what its extent?" and I camo to the.conclusion that, like the rest of the Services connected with national defence, it should be treated on the broadest lines, because its object, nature and extent will depend on the relative power of our Navy, and the objects for which that Navy exists.

My argument is as follows:-

1. It is of vital importance to us to have command of the sea, in order to keep open our Imperial communications and protect our seaborne trade. If wo fail in that wo fail in all, and coast defence would be wort'.less.

2. As we must keep command of the sea, we do not require coast defence to protect us from invasion by 'a large Army; the utmost that we need fear is raiding by small forces, which can most cheaply be met by placing small mobile garrisons near such points as are of sufficient importance to tempt a raid.

3. In order to keep command of the sea, it is necessary to secure permanently throughout a war those harbours whence our Navy draws its ships, its men, and its stores, and, in order to give freedom to our seaborne trade, it is necessary to secure our principal commercial ports. 
4. If we relied on our sea-going fleets to secure permanently the safety of our naval bases and our chief commercial ports, it would be necessary to have, within striking distance of each such place, a fleet equal to the whole fleet of the enemy in being at each period of a war-a wholly impossible jdea.

5. It is possible to secure the harbours by defences placed on or based on the land, without inordinate expense.

The first four points I consider truisms which require merely to be stated; the last point, however, requires to be supported.

The truth of the point depends on two main reasons. First: In order to secure our harbours by land defences, it is not necessary to bave anything like the power which would be required if we relied solely on a fleet, because the. Iand defences need only have sufficient power to ensure that an enemy will suffer more loss in getting possession of the harbour than we will sufier by losing possession. The strength of the coast defence of a country like ours, which has to retain command of the sea, does not depend on the strength of its weakest defended port; it is sufficient to defend each port relatively to its importance. As far as I know, this theorem, on which all our coast defences should be based, has never before been publicly formulated; but common-sense has brought about nearly the required result, for we have never fortified unimportant places as heavily as places of more importance. None the less, $I$ think it is of manifest advantage that tho principle and the reason for it should be cnunciated. The theorem does not apply to defence by a fleet, because the very existence of that fleet would induce a superior inimical fleet to attack and destroy it, after which the port, if not otherwise defended, would be at the enemy's mercy.

The second reason in favour of the altogether greater economy of coast defence as compared with defence by a fleet is the fact that not only do we require less power, but that this lesser power can be obtained on land at far less expenditure in men and money.

Apart from the axiomatic reasons that on the land you have not to build expensive vessels to float your works, there is a reason which requires argument in support.

Within its arc of fire, one gun on land was always superior to one gun on a ship, owing to its stable platform, and the fact that such platform could not be sunk. I make the reservation contained in the words, "within its arc of fire," because the ship, being mobile, could sometimes place itself outside the arc of fire of the guns of the defence and yet bring its broadside to bear on them; but this advantage usually existed when short lines of defnnce were dealt with; against long lines it should have been rarely possible.

The often expressed. view that in smooth-bore days, ships were superior to shore batteries arose from forgetting that success was almost invariably due to superiority in number of guns. People knew, but did not realise that even two-deckers had an average of about 70 guns apiece, so that, counting even but one side, three sail of the line had a broadside of over 100 guns. Did anyone ever hear of a line of batteries, having 100 guns on the water front, being reduced by three ships; or of any important case where the relative number of guns available were in similar proportions? 
In those days ships had greatly concentrated gun power, which, when they could lie close to a low battery, enabled them to overwhelm the defence by sweeping the parapets or pouring projectiles through the embrasures; but this concentration of power could have been given to the shore batteries quite easily. It was not often given, because open earthworks were so much cheaper.

Whenever it was possible to defend navigablo waters by placing guns at a high level, then the tand gun entirely dominated the gun on the ship. As the ship had to lie off at least as far as to enablo its own guns to hit the battery, it was no longer possible for it to sweep clcar even open earthworks. Hits on the ramparts inflicted little or no damage; to effect anything a gun or an individual man had to be hit directly, not an easy thing at some distance with inaccurate smoothbore guns fired from an unstable platform; while the land gun had still a target it could not miss, for every hit on' the ship was effective. A consequence of these facts was that, at high levels, it was no longer necessary to shelter land guns by placing them behind the parapets and making them fire through embrasures; but they could bo placed cn barbette, thus largely increasing their arcs of fire, and rendering it rarely possible for a ship to take up a position whence it could hit the battery without being hit back. In the well-known case of the naval attack on Sebastopol, the Wasp and Telegraph batteries, which were 115 fect above water, beat off with their ten guns of which they lost but one, two of our ships, mounting altogether 140 guns, say 70 on the broadside, and then caused the abandonment of the whole attack.

The introduction of rifling increased the advantage of the land gun, because fighting could commence at longer ranges, because the increased length of effective rango cuabled a channel to be defended from a larger choice of positions, and because the increased accuracy of the gun could be more fully taken advantage of from a stablo platform. All these advantages increased as the range and accuracy of rifled guns increased after their first introduction.

The invention of automatic sights, which require a stable platform, has once more favoured the land gun, where high positions are available. The principle of the automatic sight can be illustrated by Fig. 1 .

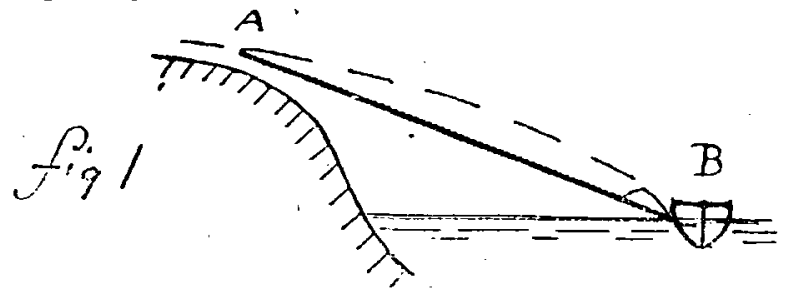

Assume a gun at $A$ and a target at $B$, then the line $A B$ is the line of sight. If you know the lieight of $A$ above water and know the depression of the line of sight, you know the range. If, then, you can arrange that as the sights move vertically the gun will move simultaneously in such a way as always to have the clevation above the line of sight corresponding to the range, then the gun layer has but to bring his sights to bear and, without estimating the range; or waiting to have the range passed to him, or, in either case, having to alter his sights to suit the range, his gun has the proper elevation.

The principle was, of course, always known, the difficulty was to apply it, for it demanded not mercly separate sighting gear for each 
pattern gun, but for cach pattern at every different height above water. It also demanded almost perfect mechanism in the mountings, and almost perfect accuracy in the laying of the platform. But when quick-firing mountings and rapid loading arrangements were invented, the advantage of having some quick method of aiming became strongly apparent, and, owing to the development of mechanical engineering, the problem was solved, in large mensure by Sir George Clarke, whose name now looms so largely before the public.

Such is the theory of automatic sighting; how about the practice? I am not a gunnery expert; but I hive seen practice with both the old and the new sights, and can say that when I first saw practice with the latter I was literally astonished. With sufficient height relatively to the range, I thought the efficiency of the firing was at least doubled.

Theoretically, of course, automatic sighting is accurate from any height above the water; but, like all things made by man, it is in practice liable to error. When the angle of depression of the line of sight is very small then a small error in sighting will cause a large error in range, and as a result, fire with the ordinary sights, though slower, might be more effective; hence the necessity for height if the advantages of the sights are to be properly utilised. I am not prepared to lay down a law-I leave that to some gunnery expert-but as an indication to those present who would like to have some idea of tho matter I can state that from a lieight of 60 feet with medium guns good practice can be made with automatic sights up to a range of a milo and a half. From a height of 240 feet the range might be about three miles. Realise then the advantage of being able to follow the ship through your sighting telescope always having the range, and always ready to fire when the gun is loaded, and you will have a good idea of the position.

From the foregoing series of arguments, I submit that I may thus sum up my case so far as it has gone. That coast defence witl us must be wholly subsidiary to naval requirements, using the word "naval" to cover both our war and mercantile marine; that coast defence resolves itself in our case to harbour defence; that though we must have command of the sea wo cannot rely on having that command everywhere at the samo timg throughout a war without intolerablo expense, and that hence some cheaper form of securing our naval bases and our principal commercial harbours than defence by fleets is necessary; and, finally, that this coast defence can be provided without extravagance by land works because at each harbour it is only necessary to provide defensive power proportionate to the importance of that harbour and because such powe" as is required can be provided on land incomparably cheaper than on the water.

Having stated the principles on which $I$ think our coast defences should be based, I will give an illustration of the method in which they might be carried out in an imaginary case, indicating how at almost every step our two great Imperial interests, naval supremacy and freedom of commerce, should guide our arrangements.

Let us consider the case of an imaginary harbour, with two entrances, to illustrate an important point. See sketch, p. 517.

It can be readily understood that a simple way of defending a harbour is to block it altogether against entrance, as the Russians did at Sebastopol; but that if we have to afford free ingress and egress 
to our friends and deny them to our foes, the problem requires more complicated and more expensive arrangements.

With us, harbour defence must be entirely subsidiary to the interests of our war and mercantile marine, and hence we cannot adopt the cheap passive defenco except where a harbour has two cutrances, when possibly-it might be admissible to adopt that form at one entrance. If this be done it should be no secret; the fact should be publicly announced.

In the case we are considering, I assume that one entrance may be closed to both friend and foe. As the navigation of the western entrance is easier than that of the eastern, I choose it as the one to be kept open, thus sacrificing the purely defensive viow to the requirements of our own ships. A nation with a weaker Navy and less dependence on its seaborne trade might very well reverse the procedure. At the western entrance every step taken must be subsidiary to the necessity for affoiding reasonably free passage to our own ships.

I assume that the harbour has importance on the whole equal to that of Plymouth, which has an important dockyard on its shores.

The accompanying sketch will enable those who are not experts to realiso what $I$ mean when $I$ use the term "combined arc of fire." The figure represents a ground plan of a battery.

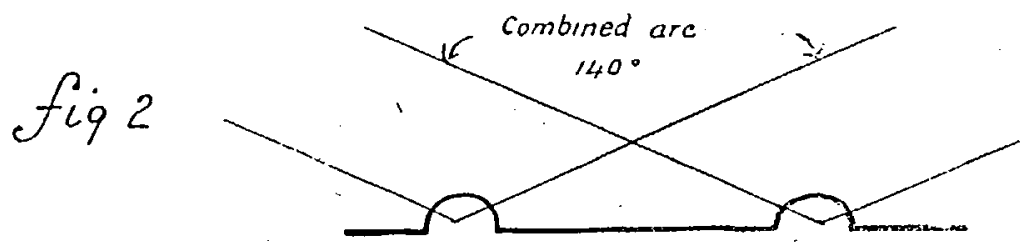

From a centre on the right front there are two lines drawn, making an angle of $140^{\circ}$ between them, and a similar pair of lines on the left front. These lines represent the limits of the ares of fire of guns piroting on each centre respectively. The inner lines cross in the centre, making again an angle of $140^{\circ}$. Now, the outer area beyond the crossing enclosed between these two lines is within the combined arc of fire, that is to say, that, as in Q.F. batteries, the gun on the right may not fire within $20^{\circ}$ of the direction of the one on the left and vice versa, only the area $I$ have just defined is under the fire of both guns.

It is not considered admissible to place Q.F. guns closer than 40 feet apart. My own opinion is that the distance should not, except for strong reasons, be less than 50 feet, on account of tho effect of noise aind blast from a gun fired so nearly in one's direction as $20^{\circ}$, because, though small, they are rapid-firing guns. With medium guns the distance apart is 100 feet, and with heavy guns 150 feet, and as both heavy and medium guns may not fire within $30^{\circ}$ of the clirection of an adjoining gun, the combined ares of fire are reduced to $120^{\circ}$.

I have described these amangements in some detail because I would like to add an cpinion to the effect that though the distances suffice when a detachment has only one gun other than its own in the same group, they do not suffice when there is a gun liammering away at each side. I would like to see all guns in groups of two, and, when there is more than one group on the same terreplein and on the same 
general front, I would give spaces between groups at least 50 per cent. greater than the interval between the guns of each group.

To return now to my harbour, I will deal mainly with the western entrance, which, as it has to be kept cpen, is the mure important.

The line A B indicates the ordinary course of navigation taken by ships entering the harbour. In our case it would be wrong to alter or interfere with freedom of navigation along that line; it should be kept well clear of obstruction and no defence light so powerful as to dazzle the eyes of pilots should be allowed to shine too diretly along it.

The necessity for giving freedom of navigation to our own ships raises the question of distinguishing friend from foe. It is a very difficult question.

Some years ago, during naval manœuvres, I commanded at a defended harbour, my main duty being to try a method of meeting the difficulty. The method was found too complicated, and has been abandoned. Though I may not even now describe tho method tried, I should like to say something about what took place.

On two occasions the defence gunners fired on ships belonging to our own side, and a special correspondent of the Times wrote a series of diatribes against the military on the strength of a signal which hat been communicated to him. I wrote shortly in reply to the effect that as the instructions governing the entrance into defended harbours in time of war were strictly confidential, the correspondent could not know what he was writing about. I did not then add, what I now can, as the system has been abandoned, that the correspondent's ignorance was so complete that the answer to his diatribes was contained in the very signal which he took as the foundation for them.

The correspondent's lettor started off a host of self-constituted authorities. One original person said that no matter who was to blame it would be little satisfaction to the nation if it lost two of its. own ships in time of war. Good heavens, what on earth were wo doing but trying a method of preventing that, and how could we try the method if we did not rigidly adhere to its' instructions? Did the man really think that our gunners aro to recogniso all our own ships even in the dark, and pass them whether they comply with the regulations or not? Please understand that $I$ am not saying who failed. That is not necessary in this case, for the writer said it did not matter who was to blame.

Another individual of the same class took up the text. I must mention one of his clarges, as it is instructive. In the course of pointing out that our methods of coast defence in some ways were foolish, inasmuch as they were more injurious than advantageous, he said that it was our practice to disregard the necessities of our own ships and sometimes threw powerful search-lights in the eyes of navigators so that they could not steer. Such may have been done in making trials; but so little truth is there in the charge that I need only answer that, for upwards of seven years at least, no defence light has been permanently installed without the Board of Trade being first informed of the position of the light and the direction in which it is intended to shine, and permission obtained for erection.

Lieut.-Colonel Maude, lecturing recently at Aldershot, condemned the scurrility with which the officers of our Regular Army were attacked by many special correspondents during the recent war. Though it is 
often the privilege of "Our Own" to be wise after the event, how very wrong he often is even when he has that privilege. Their very profession induces among gentlemen of the Press an effort at omniscience, with the consequent tendencies to dogmatic judgment on matters of opinion, and pretence at knowledge when they don't know.

I have said that the system tried was abandoned. I do not know what the present system is; all $I^{\prime}$ know is that it is something very unlike the one tried by me. But I must give a general idea of what, in my opinion, must be included in any system in order to show how it governs the whole scheme of defence against large ships.

Near the mouth of every defended harbour there would be a war signal station. So far from trying to keep its position secret, I would during peace publicly announce the position in which it would be placed. The duty of this sigual station would be to communicate with overy ship approaching the harbour. Everything secret in the way of communication would be here carried out. If the replies of the ship were satisfactory, it would be given permission to keep on its course; if not, the batteries would be informed so as to fire at or to warn off the ship. It follows that batteries should be placed so as to command as far as possible the whole area within the purview of the signal station. Morely to give satisfactory answers to the signal station ought not to givo complete entránce; it should only allow vessels to enter an arca wherein they can be boarded and examined. As the weather would often prevent this being done in the open sea, the examination area must be fairly sheltered. The inner limit of this area, which should, in my view, be made publicly known for every defended port during peace should be a lino with a definite bearing from some point whicls is marked on all charts. Ships crossing the line without anthorisation would be fired c.n. Manifestly, to guard against a ruse, strong defences slould exist to cover some area behind this line.1

Whatever the system adopted, I can say with absolute conviction that all the arrangements governing the entrance to defended ports in time of war should be in charge of the Royal Navy. The Army should have nothing to do with them, except when informed by the Navy to fire at an inimical or warn off a doubtful ship. One great point is that the regulations should be so clear and so well known that friendly vessels can make no mistake.

Now, as to the application of this system to the harbour weare considering. I place the signal station on Signal Point, which I prefer to Marconi IIill, which is often enveloped in mist; besides we want the closest inspection. As to the examination area, mere inspection of the plan indicates that the narrow part hetween West Flat and East IIill is capable of strong defence, while outside it is a fairly well sheltered area. I therefore assume that the Navy would be asked to fix a well-defined line across the channel, a little distance below the narrows, so as to give time to the defence, and yet not so far down as to unduly limit the area in which the examination will take place.

The point I have now reached is a good one for discussing the question of a mine-field. Whether a mine-field is to be placed or not is purely a naval question. If not provided, the gun defence must be stronger. In this case I assume that it will be provided, and naturally

1 It must not bo thought that this forms a complete scheme, it is on! a portion ce a scheme; there would necessarily be many other regulations. 
place it across the narrcw part. Again you may ask-Will our own ships run riaks? Practically none. I am divulging no secret when 1 say that no nation dreams of using mines which explode on mere contact; if they did, there would be many cases of the sapper berng holst with his own petard. Contact mincs are more dangerous to friend than foe the latter may not ccme near them, the former would have a ticklish job in laying and removing them. All mines are fired by an act either as deliberate or nearly as deliberate as firing a gun. But there are objections in our case to a continuous minefield. The main ones are that our own ships passing

IMACIIARY HARBOUR.

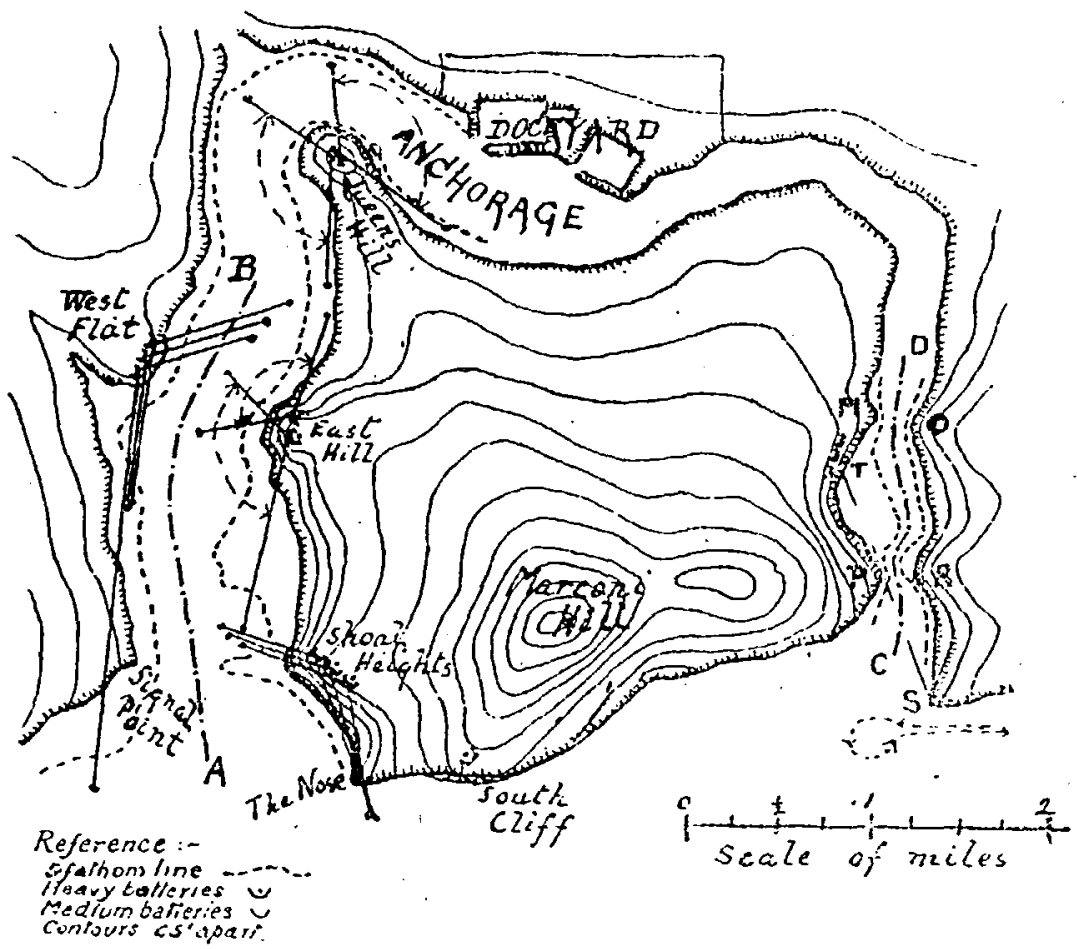

in and out would damage the mines and their connections, while the cables might entangle the screws of passing vessels. For these and other minor reasons we should have a friendly passage through the minefield along the ordinary course of navigation. The width of that passage should be fixed by the Navy and the Board of Trade, but I can conceive no case when it would be necessary to make it more than 300 yards. wide. In the case in point, its sides might be 150 yards at either side of the line A B, in which case, as the channel at the narrows is about 1,200 yards wide, three-fourths of it would be absolutely barred to big ships, and only be passable to torpedo-boats if they were prepared to sacrifice, not merely the leaders, but a second and pcessibly a third line as well, a loss that would probably act as a strong deterrent. 
But as regards torpedo-boats, we want to be "sure"; prcbable safety is not sufficient. We may not interfere with the friendly channel, but surely we can anchor booms behind the two minefields, along the line between the north corners of East Hill and West Flat. As the channel is 1,200 yards across, and the friendly channel 300 yards wide, this would mean two booms, one about 500 yards, and the other about 400 yards long. Such booms would so back up tho minofield that we could say with absolute certainty that no torpedo-boats could get in except through the friendly channel. The booms would have an incidental advantage, because they would force bargees and such like truculent navigators to keep clear of the minefield, which they might otherwise damage in passing.

I read the other day a review of an American book on Coast Defence, from which I gathered that the author proposed to place a minefield out to sea in front of the entrance. This seems to me an extravagant proposal in any case, but also an inefficient one, for in such a position the mines would be exceptionally liable to damage, and there would be great difficulty in repair. At any rate, such a proposal is utterly unsuitable to our conditions.

I have now prepared. the way for a description of the gun defence. This divides itself into anti-torpedo-boat defence, to which I barely allude to-day, and defence against large ships.

Defence against large ships is divisible into threc, though all three overlap :-

1. The outer defence.

2. Defence of the channel.

3. Defence of inner waters.

The object of the outer defence is to keep the enemy well off the port and cover the area overlooked by the signal station. The sketch sufficiently indicates the area covered by the guns, which have their full arcs of $120^{\circ}$ to the open sea, and which can all be brought to bear on ships making the entrance, while the right-hand guns of each battery can follow an enemy for varying distances up the channel. The two outer batteries have each two heavy guns; the inner one two medium guns. It will be noticed that the point called "The Nose" defilades the batteries from any position whence they might be attacked withour all the guns being able to reply; that is to say, all the area from which the batteries can be scen is within the combined arc of fire. The sites are high.

To defend the channel from the mouth inwards I naturally select the narrows. As the outer edge of the plateau called West Flat makes an angle of nearly $30^{\circ}$ with the direction of Signal Point, it can be arranged for all the guns to cover the chamnel right round from Signal Point as far as the combined arc of $120^{\circ}$ will permit. Included in this arc are tho whole of the narrows, so that the weak point-the friendly channel-is under a powerful fire. Though the height of the guns is only 60 feet, it is enough to allow the use of automatic sights at all ranges inside the entrance; in fact, just where they would bs most useful. As Signal Point is not ligh enough to hide the batteries from the sea, it is advisable to throw back the line a bit so as to give fre over the point, but $I$ would not do that at the sacrifice of a single portion of the fire over the friendly channel; especially as ships trying to enflade the batteries from a position 
whence their fire could not be returned by all the guns they were firing at would, at any rate, be under fire of the right-hand gun of the right battery, besides the fire of the guns on Shoal Heights. I think three batteries of two medium guns each will suffice for this site. It can be seen that all the guns include in their total arc of fire an arc of about $50^{\circ}$ to the open sea, which enables them to strengthen the outer defence.

Though East Hill is not so suitable for a line of batteries defending the entrance, one can place on it batteries with different fronts. My design is a battery of two heavy guns with an arc of fire that covers the deeper part of the entrance and the open sea beyond, through an arc of $25 \circ$, and continue's to the right till it includes the friendly channel underneath. I arm this battery with hcavy guns, so as fully to take advantage of the height of the hill. Further in I place on the same hill a battery of two medium guns which, while including the friendly channel within their arc of fire, cover with the rest of it an area inwards and not outwards. This brings me to third section of the gun defence, namely, that of inner waters.

I know that high naval and military authorities are opposed to this class of defence, but I know that equally high authorities of both Services are in favour of it. It is a question which should be thoroughly examined and settled. Its object cannot be defence against large battleships or cruisers, for no admiral would be mad enough to serid ships costing a million of money, and taking from two to three years to build, to rush a channel defended by mines and heavy guns, knowing that after they have got in they have to get out again, if they are not to be lost to him. This class of defence cannot be meant against torpedo-boats for, as they would invariably attack at night, they could not be seen, for who would think of lighting up waters in which his own ships were at anchor? I have sought for an object, and think it can only be that, prior to declaration of war, an enemy might open the ball by sending ships of little value to destroy peaceful shipping lying in the harbour, and to blow up dock gates and do as much such-like damage as possible till they are sunk.

To resist this class of warfare perhaps medium guns would suffice. In the case in point the battery on East Hill, which assists in defending the friendly channel, might cover, as shown, the reach inwards. On Queen's Hill two more guns with an all-round fire could be placed. The combined arc outwards includes raking the narrows, while the inward arc covers the anchorage and the waters off the dockyard.

A better way of meeting a raid made'by large ships before declaration of war is to prevent the enemy from getting in by taking the necessary steps when war seems imminent. Supposing the Navy were not prepared to prevent such a raid at all harbours, and that the one under consideration required to be protected by the land service, I would recommend that the whole or part of the regulations governing entrance should be introduced in good time, and then rely on dirigible torpedoes. A dirigible torpedo will certainly sink a ship attempting to rush a cliannel, unless the navigable pcrtion be over a mile from the torpedo installation. Now, supposing that the minefield has not yet been laid, and that the artillery garrison has not yet been brought up to war strength, still, if the torpedo installation. bo ready, and be large enough to allow, say, three terpedoes to be fired in succession, I think such a raid would fail. 
I have said that gun defence of inner waters cannot be intended to destroy torpedo-boats.' If a raid by a number of these little craft were made before we were ready with our full anti-torpedo-boat defence, I dcn't see how to stop it; at any rate, it cannot be done by the land service. In my opinion, dirigible torpedoes are of little value against a mosquito fleet; to use them thus would be like firng cannon balls against a line of skirmishers. The lesson seems to be: "Get ready to meet a torpedo-boat attack immediately war seems probable."

Looking at such a defence as I have described, you will observe that consideration of our own naval requirements has been my guide throughout.

"What!" it may be said, "you consider eighteen heavy and medium guns sufficient to defend such a harbour with an importance equal to Plymouth?" My answer is Yes, in combination with a minefield covering three-fourths of the narrows and a dirigible torpedo installation capable of firing three torpedoes in rapid succession. Recollect that I have hitherto been dealing with an attack by a fleet, not with a raid by torpedo-boats, for such require separate treatment. I believo such a defence as I have indicated, if it did not beat off an attack a outrance by $\dot{a}$ large fleet, would inflict such damage on it beforo succumbing that all the damage the victors could inflict inside would not repay them. Realise that the victors cannot land to any extent, for riflemen could shoot down the landing parties, and every defended harbour will have an infantry garrison. The main damage the ships could do would have to be done by torpedoes and by shell fire. It dare not do much of that sort of thing, else it would be at the mercy of the first battle-ships of ours with full magazines that arrived on the scene. I say that no attack by a fleet alone is likely to be made on such a port under any circumstances; and to expect it, when the enemy can only have temporarily command of the sea at this point, is to give him credit for folly-folly which we should be glad for him to commit.

Then why defend it so strongly? Because I may be wrong, and the expense involved is not great, and, moreover, it may be considered desirable to dispense with the minefield at one time or other. One should not be too cocksure. Many high military authorities thought one army corps with the Indian division and such troops as were in South Africa in October, 1899, would suffice to conquer the Boer Republics. I confess I thought so, too. Well, we lived to see the equivalent of six army corps carrying on the war for many months.

Should it be thought that more should be done, I would put a battery of heavy guns on South Cliff, where shown, which could join in the defence of the western entrance and prevent a ship circling off the eastern in the manner indicated by the dotted lines.

Time prevents me from dealing with the question of torpedoboat raids, but the details of such would not materially help to illustrate the matter looked at from an Imperial standpoint. I desire, lowever, to indicate a few general points.

The defence lights which should steadily illuminate the outer area should emanate from East Hill. If they were placed on West Flat the one that looked due south would shine directly along the line A B, which would interfere with the free navigation of the entrance. 
Another point, and one of vast importance, is this: I have laid stress on the tnormous cost of modern men-of-uar, and the time it takes. to replace a lost one, and indicated how little likely an admiral would be to waste them against land works. F'or precisely the same reason how necessary it is to protect these raluable machines from being destroyed by a mosquito Reet. What a prize for torpedo-boats if a raid by, say, twenty or thirty of them, managed to sink three or four battle-ships; what matter if all the boats were lost, it would still be a victory.

Just as I think that we overdo our defence by heavy guns, so $I$ think we are apt to underdo defence against torpedo-boat raids. Irlite I think few will support me in thinking such a defence against large vessels as that I have indicated would suffice if the harbour were as important a commercial port and naval base as I'lymouth, I believe that the anti-torpedio-boat defence which $I$ would recommend would be scouted as altogether overdone. 1

When I settled that the eastern entrance was to be blocked, but little of importance from a national standpoint was left to say concerning it. Suffice it to say that I would cover about half the basin with mines from the narrows at $M O$ southwards, that across MO I would place an exceptionally strong boom, and to prevent armoured boats from coming in to destroy the obstructions $I$ would have four medium guns. For night work I would have simply one search-light placed at $T$, where it would be defiladed from the open. As it would not have to carry far I would give it a $30^{\circ}$ splay, so that it could lighit up a considerable area at the same time. Against a torpedo-boat raid, if such madness were attempted, I would assist the heavier guns with four quick-firing guns. I would place the medium batteries to the left of the light, so as to cover any position whence the light could be hit, with the quick-firing guns to the right of the light.

In case it were considered desirable to make arrangements, while denying entrance to all vessels, to allow egress to our own torpedoboats, the matter would scarçely be altered, for the consequent passage through the minefield need only be thirty yards wide, and, if commencing at a movable portion of the boom near $O$, and directed in a S.W. course on leading lights inside $P$, there would be but little loss in defensive power. Even if egress for large ships were required, and, in consequence, a wider and more direct friendly channel became necessary, the only changes I would make would be to light up the whole basin and double the number of Q.F. guns. The defence would be assisted by a battery placed on South Cliff, before referred to, for it would prevent a ship from circling cf the entrance and making practice by firing at the boom and the minefield, while avoiding the guns of the defence.

In the early part of this paper I said that it is only necessary to defend a harbour relatively to its importance. Suppose my imaginary harbour, instead of having the almost constant value of Plymouth, were to be a mere coaling station for the fleet, then how different its value, according as a fleet is anchered inside or not.

'These two paragraphs wero written and handed in to the Editor, R.U.S.I. Jounvil, before the news of the outbreak of war arrired. Since then no word has been altered.

vol. xuvirr. 
In such a case, what value should bo put on the harbour when deciding on tho strength of the land defence?

Here again the question of defence against large vessels and against a mosquito fleet must be kept separate.

As regards defence against large vessels, I would merely rank the port at the largest non-elfective value that it is likely to live inside, including under the head of non-effective not merely colliers, storeships, and merchantmen, but also an allowance for ships of war temporarily out of action. I would add nothing on account of effective fighting ships, because, just as they add to tho value of what is inside; they also add to the defensive power.

Against torpedo-boat raids tho matter is altogether different. If the harbour be within striking distance by torpedo-boats of any foreign port, then, if the harbour be likely to have a fleet anchored inside for any considerable period, the anti-torpedo-boat defence should be nearly as strong as if the harbour had the importance of Plymouth, because in neither case should torpedo-boats be allowed to get in. I say nearly as strong, because a fleet while inside could lay down a minefield and a boom, or add these defences to such smaller minefield as may be ccmsidered sufficient for tiie ordinary case of the harbour. Ifere again it is a question for the Royal Navy to settle: How much extra will they be prepared to do in such a case, and, consequently, how much shall be done by the military? Please noto carefully that in saying "nearly as strong," I only include mines and booms, for in both ccritrasted cases the number of defence lights and the number of Q.F. guns should be precisely the same.

In concluding my paper, I would ask whether the time has not come for handing Coast Defence over to the Royal Navy. As it is entirely subsidiary to naval considerations, why bring in division of responsibility, especially as such division is most acute at the very placo where there is most difficulty, viz., at the entrance? Such a proposal does not mean abolition of our Fortress Artillery or Fortress Engineers, it merely means that those bodies would be included with the Corps of Royal MTarines. In every large fortress the whole defence on the sea front would be in charge of the Navy, that on the land side of the Army, the duty of the governor of the fortress being to malie them perform their separate duties for the common end. Such a division of duties and separation of responsibility seems to be simpler. and more logical than a system which involves joint responsibility, first, for every question connected with the principles on which the defence should be based, where naval considerations alone should be paramount; and, secondly, joint responsibility at the very place where mistakes are most likely to occur.

Admiral F. Annex Cuose:-Permit me to thank the lecturer for the information he las giren us. If there is a fault to find in the lecture, I rould say it is rather more scientific than practical, for this reanon : Submarino mines are unreliable, and aro useless against disguised gunboats. Wo hare recently had an instance of self-ilcstruction, by a ship being blown up in the face of the enemy while trying to lay mines at Port Arthur. I hoped that as a Royal Engineer inas to give us a lecture on const defence, we should hear what was ready for the defence of the const. The meeting may remember that in years gono by schemes were proposed by foreign offices for the invasion of this country, and at the licad of that list alwars appearcd the Bristol Channel. I mado it 
my business to look after those defences, and found that they consisted of two fortified islands called Flatholmes and Steepholmes, with a battery calked Brean Down to correspond with it on tho mainland. The guns were old and almost useless, and there were no gunners or garrison; nothing ready for immediate defence. Tho mayor and people of Bristol petitioned the Government that the coast defences of tho. Bristol Channel sliould be reorganised. We have now a gun-boat, Naral Volunteen, and sis now batteries. That leals up to a question I wish to put to tho lecturer : Do you, in constructing theso maritime forts, scek the advice of naval officers? I do not mean the narad officer stationed at the War Office; but whether a naval officer goes down to theso maritime forts, and sees that they are constructed not only thoorotically but practically? Without the assistance of a naval officer no maritimo fort can be as scrviceablo as it should be. Tho other question I wish to ask is : Are our maritime forts ready? Bccause if they are not ready, what is the uso of them? as war will como upon us like a flash of dightning. Again, take the Thamesanother weak point in our defences. Is I stood on the bauks of tho river at Tilbury and saw the enormous number of merchant-ships flying by on the flood tide, I asked mrself : How are me going to stop this? Any one of these ships might have a charge of dynamite on bocrd; any one night be a gun-boat in disguise. I wrote a letter to the Globc, and the Editor was pleascd to put a heading: "London bombarded; Lendon in flames!" Two powerful forts have since been built between Tilbury and Sheerness. London is now safo from general attack; but if Germany was to declare war on Monday morning, thos could have a couple of disguised gun-boats up in the mitdle of London by tho next night. Theso maritime forts have no means of knowing the difference between a friend and a foo under falso colours, and when it comos to disguising gun-boats to mako them look like a merchant-ship and under falso colours, they would not be interfered with at all. - I say that Irondon will never be safo until Te almays hare a couplo of gun-boats stationed there, becauso at tho present moment if gun-boats got up past Tilbury to London, there is nothing to meet them but a police-boat; there is no lnowing what haroc the gun-boats might do. They might blow up the bridges, destroy the Houses of Parliament and tho decks and shipping; also Woolmich Arsenal and the magazines at Purfeet. Jondoners do not understand that. Iondon is no longer an inland town, and is ns much exposed to attack in these dass of steam power as Hull, Lirerpool, or Glasgow. London is under military protection, and as it is impossiblo for them to perfect that protection without the assistance of the Nars, I submit thoy should ask for that assistance now, not waiting for the outbreak of war.

Colonel R. F. Jomsson, C.M.G., R.A.:-I happen to have been the Artillery officer in charge of the Serern defences for two sears, and $I$ am happy to say that while I was there there was no insubordinntion nor drunkenness, and the forts were perfectly reads for action. I cannot say that it mould have been much good to man them, because at that time the guns had not boen replaced bs new ones; but with regard to manning them, we had a most excellent and rery strong corps of Volunteer Artillery in Cardiff, within half-an-hour of the nearest fort, and within tiro hours of tho farthest fort. The men wero perfectly trained with all the guns that were in those forts. The lecturer has giren us an example of tho application of what ho considers aro the principles of coast defence. $\mathrm{My}$ practical experience makes me afraid of principles when thè are applied

$$
2 \text { is } 2
$$


to such matters. It was principles that led to sereral of our home portis being fortified on a scale calculated for a total of garrisons amounting to $67,000 \mathrm{men}$. The principies that liave led to the conclusion that the heavy land detiences of some of these forts are not necessary, hare caused those of others, whose conditions are entirely - different, to receive insufficient attention. The adoption of principles in placing guns has in some instances provented the best use of the arailabie sites. I know a work in which the changes in tho conditions attaching to ships has mado it desirabis to alter the dircetion of the "combined arc of fire." When I discussed this with an Engineer officer I was told it could not be done, because the site did not admit of its being so, and of retaining the regulation distanco between the guns. We did not want the arc of fire to bo near the guns. Where we wanted a combined are of firo was a considerable distanco off, so that the blast need not have been taken into account. Tho principle, which in itself is perfectls corrcet, that high sites enable better. practice at targats from cheaper works, has prevented the use of low ones, which from thoir proximity to the channels that must be used by shipe would enable us to make use of the greatiest power of our guns, if they wero armaired and protected in tho way those on the ships are, which is our only chance of denying tho passage to a determined assailant. I entirely agree with tho lecturer when he says that a harbour with an inportanco equal to Plymouth may be sufficiently detended by 18 heary and medium guns; but whether Plymouth could be defended by that number is quite another matter. If the guns were of sufficient power, properly placed, and sufficiently protected, eren a smaller number might suffice. And it is especially necessary to limit your armament and fortifications nowadays, because it is more inportant than erer that they should be just as ready in every way, including their garrisons, for action as the ships that they have to fight. Tho only principles that I can accept with regard to coast defences are that they shall be strictly confined to places mhero the Nary thinks them necessary, and that their extent and cost sha'l bo as small as tho local conditions, strategical and tactical, admit. I am sure that there might be a great saving made in the annual cost of our sea fortresses, though possibly a considerable capital expenditure might ten necessary to enable this to be done. Whether you should defend the entrances or the inner waters of a harbour depends on the strategical conditions, on what damage to that which you are defending is rorth to the enemy, and on what he can afford to pay. Can anyone cite an instance of batteries stopping completoly tho passage of a channel? If such an instance can be giren, it is certainls the exception that proves the rule, and the chances of armoured ships getting through are now better than they havo ever been. Suppose Port Arthur contained the only Russian dock in the Far East; suppose that the Japanese Fleet had either a ship or tro to spare, or was tco weak to meet the Russian Fleet in battle; then, if the Russian Fleet was elsewhere, would it not in either case be worth while for the Japanese, whether in decided superiority or decided inferiority, to risk the loss of a ship or two, if the absence of inner defences gare them the chance of destroring tho dock? It secms to me somewhat lost sight of, that in defending chaninelis by guns, and more so by mines, there is, in not a fer localitios, a danger of blocking with the sunken ships the channels it must be your object to keep open. I am entirely opposed to the proposal to hand over coast defence to the Royal Navy. The proposal is tempting to a Garrison Artilfergman, for in the mork of defence the Navs must have more interest than the Field Army. We should get more money for the adjuncts 
necessary to derelop the full powers of our armament; wo might get rid of the principles of fortification, but the corps would suffer a deadly injury in having its chances of active service reduced to almost nothing, and the disadrantages to the $\mathrm{Navy}$ woukd be out of all proportion to any possible gain. All naval energios should be directed to offensivo action; and, with our Constitution, it is necessary-that tho Naval Estimates shall not be burdened with any expenditure not required for that offensive action. $A$ Const Defenco Corps, entrusted with both the designing and fighting of tho deiences both seaward and landward, maintained on separate estimates, and at somo places largely composed of partially-paid local troops, might perhaps bo an improrement on our present organisation; but that is a large matter on which I should be sorry to bo asked to giro a decided opinion, for though the idea meets some views worthy of consideration, it has the great objection of locking up large numbers of men and officers, and in such a way as to lower their moral and zeal.

Lieut.-Colonel F. G. Cotrer, R.M.L.I. :-It is only with reference to tho last paragraph of the lecture that I'riso on this occasion, because on such a highly technical lecture that wo have just heard it would bo absurd for me to make any comments on the details. There wa; ono matter with referenco to the defensive arrangements that struck mo-and always strikes mo-as a weak point, and that is the defence lights. It appears to mo to be essentiaily a rery vuinerable point, especially at night timo, when of course their location is at once seen, and would be the object of raiding parties landed on various parts of tho ceast, and also open to attack from quick-firing guns carried by destroyers. I have heard it said that you cannot aim a gun at an electric search-light; but that is not my experience. I say you can aim a gun at an clectric search-light, and probably hit it, too. If the search-lights in the harbours like Plymouth or on the. Thames were dẹstroyed at night, what is to prevent torpedo-boats coming up the very next night? That is all $I$ wish to say with reference to defence. The only other matter I desiro to refer to is the last paragraph in the lecture, namely, tho proposition to hand over the fortress defence to the Nary. The author mentioned the Royal Marines as being the soldier body of the Nary, and suggested that tho Fortress Artillers and Engineers should be, I supposo, amalgamated with tho Rosal Marines. We know that this subject has been brought up in this theatre on various other occasions, notably by Sir John Colomb, and wo know perfectly well that the Admiralty have always set their face against it. I presume the reason that the Admiralty has always done so is lest the efficiency of the men-of-rar should suffer through not having the men constantly on board, becuuse, of course, it would mean increasing the Marine Corps to probably about fire times its present strengtl.. Another thing is that the Admiralty haro recently reorganised the system of entering officers into the Nary. The officers aro now entered so that they mas be practically interchangeable with all three branches. . Wo have no experience of that as yet, but wo know perfectly well that the system has already been commenced at Osborne in the Isle of Wight. The result is that the future naral officer will have quite enough to learn. Ho will have to learn his seamanship up to a limited extent, I suppose, but certainly to a certain extent; he will have to learn his naval gunnery and his torpedo work; and he will now have to learn marine engineering and military work, as the present marine officers do, in addition to which he is apparentls to have piled on him the work of the defence of sea fortresses, no that it would result in the naval officer of the future being ratlwer orer-burdened 'with work, and he would become a cort wi Jack-of-all-trades. Then, with regard to the Marines, 
we know that the Admiralty consider them a very raluable body of men on board ship. Some people think that Marines a ro of no use on board ship. My experienco is that on asking naval oflicers whether they would like twenty additional men attached to their rossel, and whother they would have them seamen or stokers or Marines, I havo nearly almays been told that they would ratler have twenty additional Marines, which ahows that the Marines on board ship aro thought very highly of by the naval officers. The Marine, of course, would lose his value very considerably if ho oniy spent ono year in ten at sea, lecauso I sco tho Iecturer proposes to man all tho sea fronts of all fortresses with Marines, or, as he says, men from tho Navy. But ho does not tell us who is to conmund these fortrosses, whother thoy aro to bo naval oflieers or military officers. In one part of his paper ho suggests that the sea fronts shail be defended by the Navy or Marines, and tho land fronts by tho Army; but that is also a divided responsibility. Wo therefore do not know who is to command tho fortresses. It may bo a naral officer. If so, he would also apparently havo command of the land forces on the land side.

Admiral the Hon. Sir Edyixd R. Fremaxile, G.C.B., C.Mr.G., Rear-Admiral of the United Kingdom):-I have not read the lecture, and consequently I do not feel entirely competent to criticise it in erery was. I shall, therefore, confine my remarks chiefly to the question of principles, and also to somo things which I think show the way in which we ought not to dofend our ports. I take exception to the fourth principie laid down by the lecturer, that "if we relicd on our sea-going flects to secure permanently the safety of our navei bases and our chief commorcial ports, it would bo necessary to have, within striking distance of each such placo, a flect equal to the whole flect of the encmyi in being at each period of a war-a wholly impossible idea." I venture to think that is a falso idea of strategy. I admit that we did not fortify Wei-Hai-Wei on that principle. Wo say that if wo were to fortify Wei-Hai-Wei we should have to fortiny it against the attack of a flect, jossibly a Russian fleet from Port Arthur, and, therefore, as wo do not propose to put up extensivo fortifications there, we do not put up any at a?!. I do not think that is the right principle of strategy. If there is a Russian fleat in Port Arthur wo ought to bo ablo to mask that flect; wo ought to keop it in hand, which the Japanese are doing at present. On the same principle I think this ono laid down by tho lecturer is wrong. If there is an enemy's fleot somewhere at Cherbourg, and wo have got a suficient fleet, we should bo moro or less watching that fleet. Eren supposing our fleet was away for a littlo timo, and tho French fleet could manage to slip out, would it bo a wise thing for that French fleet to como to Plymouth, to do a cortain amount of damage, but in returning to bo knocked about as well, possibly to lose the whole of their fleet? After all, if thes lose the whole of their flect it does not very much matter if wo have lost tho dockyard, as they certainly would lose their flect, bccauso our moro porrerful fleet would intercept it. But nobody does do that sort of thing. In the books that we read somotimes-wo have not seen so many of them lately-called "The Coming War," and so on, you generally see that tho fleets fight in a sort of Fillienny cat fashion. I well reccliect one that I read some rears ago, in which tho Russian fleet ras supposed to go up tho Tyne and do a certain amount of damage there, losing ship after ship, and, erentually, fortunately for us, tho whole Russian flect was destroyod. That is tho sort of thing which is absolutely and entirely unreal; it is not tho sort of thing which takes piace in real warfare, and consequently it argues a great want of sense of proportion to propese that it will be done. I hare only 
ono other remark to make, and that is on the subject of whether defences aro proper to the circumstances of a particular port or country. I should like to refer particularly to some defences near Plymouth on the west side, where a system for high-angle fire, which was very much in rogue about ten years ago, was adopted. When $I$ was in command at Plymouth, I recollect going round with the Commander-in-Chief (Lord Wolseley), Sir Redrers Buller, and others, to seo all theso detence;-chietly high-angle firo batteries, which were supposed to bo reis important, and to embrace the latest improvements. I was aslied : "What do you think of them?" I said: "I have no opinion as to their firing, becauso I haro only seen the guns fred once or twice, when they did not niake as accurate shooting as I am whld thoy did on other cccasions; bui it they made tho most accurato shonting in the world they are absolutely uscictss. The best thing you can do is to blow them up." I do not know what has becomo of them now ; but they were absolutely useless, because the assumption was that somo Power -not a l'ower that I know anything about-had the entire command of the sea, but had no land forces. It would not think of landing an army in the Yealm or in the Thames, or anywhere e'se, becauso it had no army. That was the assumption. I3ut it had any amount of mortar-boats and a large fleet; and tho assumption was that it would lie somewhere in Whitiand Bay and would shell orer the heights into the dockyard, with the chance, after throwing a very large number of shells, as we did at Sreabourg, that thoy would do a certain amount of damago to the dockyard. That is an assumption which, strategically, is ontirely wrong. And that is not the only instanco I know of, becauso a Zalinsky gun was put up near Pembroko to prevent an enemy's flect lying outside and throwing shells from Bristol Channel orer thes heights into Pembroke Dockyard. I will onls quoto those instances of the way not to do it. What wo do mant, I venture to think, is a certain amount of direct dofence, mine-fields, quick-firing guns to protect them, and a certain proportion of heary guns to prevent the enemy coming dircetly into the port. Thoso guns roulcl be proportionate to the position of this country, which is supposed to be, and, I hope, still is, the greatest sea Power in the world; and she wculd naturally be supposed to have command of the seas; and if she had not command of the seas we know perfectly weil that no amount of decences will enable her to retain her place among the nations.

Colonel F. A. Bowles, R.A.:-There are one or two questions I should like to ask the lecturer, which, perhaps, he will answer afterwards. In his lecture, Colonel Cotter states that "I am dirulging no secret when I say that no nation dreams of using mines which explorle on mere contact." I am only asking for information, but $I$ have an idea that when the elcetro contact mine, a.3 it is called, is put in rorking order, it does go off on contact. The lecturer rather conveyed the idea that the firing of a contact mine was just as deliberate an action as the firing of a gun; but $I$ think $I$. am right in saying that as seon as the mines are put in a dangerous condition the ship does the rest. I think we may safely sas that some nations dream of using them, and we know that one nation lately-if the accounts in the newspapers are correct-has certainly suffered from using contact mines. With reference to the boom at the wesiern' entrance, I understocd the lecturer to say he proposed to put two bcoms across what he called "Tho Narrows," i.e., 1,200 yards, leaving a friendly passage of 300 yards betireen them. I am not an expert in referenco to booms, but I hardly think a boom 450 sards long would be manageabie; and unless stone piers were built out to a very considerable distance; I think no boom 
could possibly be fixed in the western entrance. Even the eastern entrance, I think, is a little too wide to erect a boom. I believe it is an understood thing now that booms wili' not be very often used, probably lior the reason that there are, rery fow places which are suitable for them. I think at both tho western and the eastern entrances booms woukd be rather unwieldy things to work. Supposing a boom at the eastern entrance uas placed in tho position which the lecturer suggested, I-think we must raise the question as to the position of the electric light, becalsso the whole of the boom would be in tho full light of its beam, and I think it is not, an accepted principle that the boom itself, if you havo an illuminated area in front of it, should invariably be in darkness. I think it would bo useiul if the. lecturer would say something in repiy in regard to that point. I should like to bo allowed to say a few words in regard to some of the remarks that have been made since the lecture. With rriterence to the heavy and medium gun defence, I think all our coast defenees now are founded on the principie that England must hare command of the sea. The lecturer in his 'lecture asks, why have heary and medium guns. I think the simplest answer is : In order that me may never have to use them. What I mean by that is that I think our heary and medium gun defence is more a preventative than a form of defence that is ever likely to be of ang great practical value, because as long as we have command of the sea no serious attack on any of our well-fortified ports could ewer be successfully attempted by any country. With referenco to anti-torpedo-bont defence, I endorso what little has been said by the lecturer. I cannot help thinking that every possible occasion should be taken adrantage of to impress on anybody who has to deal with our defences the vast importance of a thoroughly organised and good anti-torpedo-boat defence. We have had no practical experience until very lately of the rapidity with which these attacks will be made. We have always said in our text-books that torpedo attacks will be made probably before. war is declared, and that has certainly been justified by recent events. What wo want is a very strong anti-torpedo-boat defence. The lecturer has also said a good deal about another subject which is still in a rather embrso state, i.e. the very great difficulty of distinguishing friend from foe. Tho lecturer pointed out what he considered would be a good system.

Colonel E. W. Cotrer :-l beg your pardon; it was a general outline.

Colonel F. A. Bow Les :-Probably a great mans of the audience know that what the lecturer considers an outline of a good system is practically a fair description of what actually was tricd at the recent naval manœuvres. It had many faultis; but no system, in my opinion, that has been tried yct, can bo bolied upcn as a perfectly successiful system. It is almost impossible-I should say it is quite impossible-for anybody, even a naval expert, to be able to tell at night the difference between his own torpedoboats and the enemy's torpedo-boats when an attack takes place, no matter what the rule may be. Supposing the rule is that friendly torpedo-boats, if they aro moving about, are to advertise their presence in overy possible way by showing ait their lights and sounding their sirens, I havo alrays maintained that it would be very easy for the enemy (who would know more about our arrangements than a great many of us know ourselves) to do the same, and, as lfar as we can judge from what we have read in the newispapers, that is what the Japanese did do; they showed all their lights; they came in as though they were friendly terpedo-boats, and by that ruse they got quite near to the Russian shipo before the Russian ships knew it-if they ever did know it-until the torpedoes had actually taken effect. It 
is difficult to know how much to bejieve of what one reads in the papers; but if wo do beliere what wo have lately read, wo know that the Russians have not only sunk their own torpedo-boat bccause they were thought to be Japanese boats, but they have also allowed their own ironclads to be torpedoed' by the Japanese because tho Japaniese torpedo-boats were thought to be Russian boats. If both those accounts are true, it only enforces still more the absolute necessity of our having some system of lnowing without any doubt at all whether a torpedo-boat moring about at night is an enemy's boat or not; and that really is the crux of the whoie thing. I think with our present system of defence of guns and lights, provided they are properly arranged to begin with, which is most important, tlat we aro in a moro advanced stato than somo of those who have spoken since the lecture are awaro of. I think we should make a very good attempt at heeping torpedo-boats out, if we know for certain that they were the enemy's torpedo-boats. It seems to me that the only possible rule which will meet with any success is that no friendi'y small boats aro to movo about at all during the hours of darkness, otherwise it gires the gunner absolutely no chance at all. A soung subaltern of the Garrison Artillery, in command of two guns, cannot take the responsibility upon himself of firing on boats unless ho is perfectly certain that they are tho enemy's boats, while if ho hesitates ha!f a moment he is lost; ho will nerer have the chance again. Torpedo-boats, once they are seen in the illuminated area, do not givo you a very long time to fire at them, and if you are not ready to begin on the instant tho boat is risible orer the sights or through the telescopes of your guns, jou get no chance. Therefere I say it is absolutely necessary to lay down the rule that no friendly torpedo-boats are to move about at night within any waters that aro defended by guns. I should like to bo allowed to mako ono or two remarks about high-angle firing, because some remarks have been mado which rather tended to show that it would be just as well to blow up high-angle batteries altogether. I am rather an adrocato for high-ang!e firing. I know that experiments were. tried at Plymouth some years ago, and I believo it was because of those experiments that high-anglo guns were condemned by a very large portion of the military world; but I am not of that opinion myself. I am certain that high-anglo firing guns can bo worked up to very fair accuracy, quite sufficient accuracy; I think, to mako them extremely useful in certain waters. Of counso, they aro not applicable to many places, but there are certain piaces where I think they would be most useful; anyhow, they would have the effect of leeping the enemy's ships on the move. I am open to correction by naval officers, but $I$ have heard it said that a naval officer funks high-anglo fire more than anything. If it does hit, it hits him in a place where he has not much protection-the unarmoured decks, and I liaro always heard that it is a form of defence that the Navy will not run the risk of encountering. I just mentioned that because I am rather keen about high-nngle firing, and $I$ think it is a pity that it should be condemned without more experiments being carried out.

Admiral the Hon. Sir F. R. Fremaxte :-I should like to say that I believe it is a fact that the Admiralty's arrangements are, on the whole, quite complete (whether they are sufficient is another question) with regard to the closing of the ports, and also with regard to distinguishing our own vessels from those of foreign Powers. Those arrangements were practically completed before I left Plymouth five years ago.

Colonel W. W. Corten, in reply, said :--It is a very different thing to read a paper and have to speak extempore; but somelow I gather from the. 
tenor of what has been said that although there has been a good deal of criticism, there is no disagreement with my general conclusious, except in regard to the one about handing tho defences over to tho Navy. That subject I left to itself, apart entirely from the rest of any lecturo. I only raised that point because the result of $\mathrm{my}$ study has brought before me the fact that at overy stage, no matter whero, I was always confronted with the query: "What would the Navy want in the matter?" I was asked a direct question by one speaker: "Were the Navy ever asked?" All I know is this, that I always asked the Navy whenever I came across any naral officer. I I knoir that the same idea that was condemned by one of the speakers about a ship lying outside the fire of the batteries and bombarding the dockyard from the open sea, caused a long discussion at one place where $I$ was, and it was raised in the first instance by a naval officer. It was not the foolish militàry officer that raised the question on that occasion, and, as General Mac:Calmont knows, I did not believe it was a practical point. I say this becauso remarks wero mado suggesting that we do not do theso things rensonably. I appeal to you whether I have not tried throughout $m y$ lecture to givo a reason for every step. I took. Throughout the whalo of the paper I have put my own branch of the profession last, becauso I felt that naral considerations in regard to caast fortresses must be entiroly paramount. Admiral Close said ne are not reads. Why! I said that I seo no defenco unless wo are ready. We must bo ready. If there be, as I said in some part of my lecturo, a chanco of torpedo-baats doing destruction in a harbour before the declaration of war, the only thing for us to do is to get ready when war is imminent, and be ready when negotiations aro broken off. I think it was Colonel Jolunson who said ho would prefer to hare batteries on a low site. I disagree with him altogether. I have not tho least doubt in my own mind about it; but ho is entitled to his orn opinions. It would be a reversion to the old argument. I rould infinitely rather have one gun in tho open with 1200 arc of fire than three or four guns with 300 arc of fire, bosed up in a casemato where they aro not so ready to firo.

Colonel R. F. Jorrsow :-I was not talking about casemates. I said in cortain cases batteries which have an all-round fire roukd be better at low site than a larger battery, because you get. shorter range, and thereforo much greater penetration.

Colonel E. W. Cotren :-Of course, if to get height jou have to go a long way off, then the advantage of your height would disappear. If my drawing were put on a scale you would find that the slope of the hills ${ }^{2}$ is 100 , so that the guns never lose more than about 100 or 200 yards range. Somebody said that the Navy should bo confined to offensire operations. There is something to bo said for that. Personally I thinl they should be confined thus :-Ererything in which naval considerations are paramount should be done by the Nars. If it is offensire it should

1 I expressed mysalf rery badly hero. Aftor lecturing for an hour-an a themo, the text of which was that naval considerations should be paramoint, I was naturally startled at being asked by Admiral Fremantle if I ever consultied a naval offcer. Answers crowded into my mind, but I could not at the moment put them into words. I Suffico it to gire but one. A naval officer was consulted about every battery built under me during my. tenuro of command as C.R.E. He was consulted before they were commenced, and he visited them during progress.-E.C.

${ }^{2} i . c$, the hills on which the hears batteries were placed.-F.C. 
be done; if it is defensive it slould be done; but that of course is a naval question. The question was raised about the anchoring of a boom. I do not seo why a boom should not bo anchored across the water whore I slowed. Of course, no boom would bo 1,200 sards long; there would be two booms in the main channel, one at either sido of the friendly passage. With regard to, the torpeclo-boats at night, I always undenstood that every torpedo-bont which attempted to enter a defended port at night would be fired at. There is one thing $I$ should like to add before concl,uding. I have said that we are apt to overdo our defence by heary guns, and apt to underdo our defence against torpedo-boat attack. In connection with that I may have been misunderstood. Tho officers who have been recently responsible for our coast defence havo shown great insight and wonderful courago in the way, in which they have placed but one gun where two or three guns wero placed before; and with regard to what thes have done against torpedo-boat attack, I can seo no improvement possible. As to the stylo of the defenco adopted, the only question is that I think we have not thoroughly realised how very necessary it is to go a great deal further on the same lines. I am very much obliged to you, Sir, for taking the Chair, and to you, gentlemen, who have discussed the paper. ${ }^{1}$

Tho Ciramuax (Major-General Sir Hugh MacCalmont, K.C.B.) :Wo have listened to a very instructive lecture and a rery interesting discussion, though $I$ do not mean to say that tho discussion was not instructive too; as far as I am concerned, it was very instructive. It occurred to me that the main point of the lecture is point No. 5 :- - "It is possible to securo harbours by defences placed on or based on the land without inordinate expense." I remember the caso of Baliast Loch; where I lived some years ago. The placo was absolutely undefended. It comprised a narrow channel leading up to a great manufacturing town and great iship-yards, which were practically at the mercy of any cruiser which thought it worth its while to rrork round and do some damage. The Navy cannot command every port; it cannot be everywhere, and it would bo quite worth the while of any cruiser to make a raid on a place like Belfast. I wrote many letters in the papers at the time I lived there to call attention to the grebit risks involved. Within the last three or four years the place has bcen adequately defended, and, as Colonel Cottor has pointed out, at quito a comparatirels trifling expenso to that of making the Nary responsible for everything of the kind. It appears to me to bo a matter ontirely of economy. There is ono question I should liko to ask the lecturer. Colonel Cotter said that these contact mines were entirely out of date. We were giren to understand that no nation would uso contact

'Addcndum.-I gather from the discussion that I did not make myself ciear in the last paragraph of my lecture. I wish I had said": "Placed under the Admiralty" instead of "handed over to the Royal Navy." I never intended that sea-going naval officers should como ashore and command land batteries, nor did that follow from tho text. Again, when I said that the present Fortress Artillery and Fortress Engineers would be included witli the Corps of the Rojal 1 Iarines, I did not mean complets amalgamation, for of courso the two existing Corps of Marines are not amalgamated. I meant that the Coast Defonce Corps should bear the same relation to tho Admiralty as do the two existing Marine Corps; but it does not necessarily follow that the new body rould be sen-going, and therefore it does not necessarily follow that the R.M.A. and R.M.I.I. would get one whit less sea experience than they do at present.-E.C. 
mines. But wo read in tho papers the other day that the Russians blew up ono of their own ships through it touching a contact mine.

Colonel E. W. Correr :-If I may answer at once, I would say we do not know enongh of what has cccurred; we cannot rely exactly on what we read in the papers. But I think Admiral Fremantio said the other day in the papers that no nation would dream of using purely contact mines. You must, in addition to the contact, have another act, a very deliberate act. Of course, when that deiberate act is taken, then if you knock against the mines you blow yourse!f up. Whether the Russian arrangements rero very bad or not, as I am not a inaral officer, I do not say; but I cannot understand them. They may have in this respect done one thing by mistake, viz.: performed the deliberato act, so that when the contact occurred tho ship was blown up. , However, we cannot tell that until we know moro about the dotaits.' But. I do not believe they have used purely contact mines.

The Curanmax:-Then I should like to say that one of the speakers inferred that the advice of naral cficers was not taken in regard to these land defences. I know of one case in paint in which nearly all the work was dono on tho initiatire of an admiral, though I cannot, of course, mention either the man or the place. At any rate, I know in one most important caso that it was entirely on the almiral's initiative certain steps were taken; and I remember his making tho remark to mo: "If you put guns of such and such calibre in a certain place no battleship will ever come near it." And the admiral's riew was acted upon. I do not think thero is anything else I need say, except that I am not altogether prepared to agree with Colonel Cotter's proposal to hand orer the coast defence to the Nary. I am onc of those people who think that everyone ought to bo allowed to do his own business, and that al the land business ought to be done by the land forces. If it is a question of signalling, then the land forces, the Garrison Artiliery, and so on, should be thoronghly educated for tho interchange of all signalling with the Nary. There is a tendency for crergbody to try to do everybody else's work. For instance, in the caralrs there are three men to one horse. Before you proride the three horses for the three men sou proceed to mount the infantry. That is our way of doing business; it is a sort of Jack-of-all-trades plan, which : am quite certain is not conducive to efficiency. I desire, on your behalf to propose a liaarty rote of thanks to Co'ond Cotter for his rery able and instructire lecture. 